\title{
INTERAKSI SOSIAL TAHANAN MASA PENGENALAN LINGKUNGAN DI RUMAH TAHANAN NEGARA KELAS I KEBON WARU KOTA BANDUNG
}

\author{
Nabela Octari ${ }^{1}$, Eni Rahayuningsih ${ }^{2}$ dan Nurjanah $^{3}$ \\ Mahasiswa Sarjana Terapan Sosial Sekolah Tinggi Kesejahteraan Sosial Bandung dan Fungsional \\ Dosen Sekolah Tinggi Kesejahteraan Sosial Bandung \\ loctarinabela@gmail.com, 2noey@yahoo.com,dan ${ }^{3}$ enirahayuningsih@ymail.com
}

\begin{abstract}
According to Chaplin in Bimo Walgito (2011:3) Social interaction is a relationship that affects each other. In social interaction there will be individual behavior as well as social behavior. This study aims to understand deeply about the social interaction of Prisoners of Environmental Introduction in the State Detention House Class I Kebon Waru Bandung by digging things like the characteristics of prisoners who are undergoing the period of introduction of the environment, social interaction of prisoners through cooperation, social interaction of prisoners through accommodation or selfadjustment, the social interaction of prisoners in competition, the social interactions of prisoners in contravention, and the expectations of prisoners. The research method used is descriptive method with qualitative approach, data in the form of written words or behavior observed intact related to social interaction. Data collection techniques used were in-depth interviews, observations, and documentation studies. The results showed that social interaction can be said to be less good. This is because the still strong culture of seniority in the cell that makes the prisoners who are undergoing the introduction of the environment can not behave in accordance with what he wants. While viewed from the aspect of Cooperation, Accommodations, Competition, and Contravention was not enough visible because of new prisoners prefer to passively in the cell in order to avoid the things that are not desirable.
\end{abstract}

Keywords: social interaction, Environmental Recognition Prisoners

Abstrak

Menurut Chaplin dalam Bimo Walgito (2011:3) Interaksi sosial merupakan hubungan yang saling memengaruhi satu dengan yang lainnya. Dalam interaksi sosial akan terdapat perilaku individu maupun perilaku sosial. Penelitian ini bertujuan untuk memahami secara mendalam mengenai interaksi sosial Tahanan Masa Pengenalan Lingkungan di Rumah Tahanan Negara Klas I Kebon Waru Kota Bandung dengan menggali hal-hal seperti karakteristik tahanan yang sedang menjalani masa pengenalan lingkungan, interaksi sosial tahanan melalui kerjasama, interaksi sosial tahanan melalu akomodasi atau penyesuaian diri, interaksi sosial tahanan dalam persaingan, interaksi sosial tahanan dalam kontravensi, serta harapan para tahanan. Metode penelitian yang digunakan adalah metode deskriptif dengan pendekatan kualitatif, yaitu data berupa kata-kata tertulis/lisan atau 
perilaku yang diamati secara utuh yang berkaitan dengan interaksi sosial. Teknik pengumpulan data yang digunakan adalah wawancara mendalam, observasi, dan studi dokumentasi. Hasil penelitian menunjukkan bahwa interaksi sosial dapat dikatakan kurang baik. Hal tersebut dikarenakan masih kentalnya budaya senioritas di dalam sel yang membuat para tahanan yang sedang menjalani masa pengenalan lingkungan tidak dapat berperilaku sesuai dengan yang dikehendakinya. Sedangkan ditinjau dari Aspek Kerjasama, Akomodasi, Persaingan, dan Kontravensi pun tidak cukup nampak dikarenakan tahanan baru lebih memilih untuk pasif di dalam sel agar dapat terhindar dari hal-hal yang tidak diinginkan.

Kata Kunci: interaksi sosial, tahanan masa pengenalan lingkungan

\section{Pendahuluan}

Interaksi sosial dilakukan oleh setiap manusia karena pada hakikatnya manusia merupakan makhluk sosial. Dikatakan makhluk sosial karena secara alami manusia akan mengadakan hubungan dengan manusia lain dan saling memengaruhi satu sama lain. Di dalam keterbatasannya, interaksi sosial pun dilakukan oleh para tahanan. Menurut Peraturan Menteri Hukum dan Hak Asasi Manusia Republik Indonesia Nomor 6 Tahun 2013 BAB I Pasal 1 Ayat 5 tahanan adalah seorang tersangka atau ter-dakwa yang ditempatkan di dalam Rumah Tahanan Negara (Rutan).

Dibalik jeruji besi para tahanan diharuskan untuk dapat berinteraksi satu dengan yang lainnya, karena seorang tahanan juga merupakan makhluk sosial. Mereka memiliki hak yang sama seperti masyarakat lainnya dalam berbagai aspek kehidupan. Tahanan juga memiliki hak untuk memenuhi ke-butuhan termasuk berinteraksi, seperti me-miliki teman, hubungan yang baik dengan orangorang disekitarnya, baik itu sesama tahanan maupun petugas di dalam Rutan. Secara kuantitatif berdasarkan Sistem Data Pemasyarakatan (SDP), data terakhir jumlah penghuni bulan Agustus 2016 menyatakan bahwa jumlah tahanan Kantor Wilayah
Hukum dan HAM yang disingkat Kanwil Jawa Barat sudah melebihi kapasitas, yakni sebanyak 21.491 orang dengan jumlah seharusnya yaitu 15.544 orang, jika dipersentasekan maka menjadi $138 \%$ yang artinya jumlah tahanan di Jawa Barat sudah mencapai over kapasitas sebanyak $38 \%$ atau 5947 orang. Keadaan sel yang serba terbatas tidak me-nutup kemungkinan dapat memicu interaksi yang negatif diantara mereka, sehingga dari interaksi negatif tersebut akan menimbulkan perpecahan dan tentunya interaksi diantara mereka tidak akan berjalan dengan baik kembali. Namun disisi lain interaksi positif pun dapat saja terjadi karena didalam sel yang serba terbatas, mereka dapat saling bertukar pengalaman dan saling

memberikan dukungan, hal-hal tersebut tergantung bagai-mana mereka dapat menjalani interaksi ter-sebut melalui proses belajar. Rumah Tahanan Negara Klas I Kebon Waru Kota Bandung berlokasi di Jalan Terusan Jakarta No 27, Kebon Waru, Batununggal, Kota Bandung. Rutan ini berkapasitas sampai dengan 2000 orang, namun jumlah tersebut bersifat dinamis dan mengalami perubahan setiap harinya. Terhitung bulan Mei 2017 jumlah dari warga binaan pemasyarakatan secara keseluruhan adalah 1.476 orang yakni 634 tahanan yang belum mendapatkan vonis dan 852 warga binaan yang sudah mendapatkan vonis. Rutan 
Kebon Waru terdiri dari empat blok yaitu Blok A sebanyak 31 sel, Blok D sebanyak 31 sel, Blok E sebanyak 29 sel, Blok F sebanyak 29 sel. Berdasarkan hasil penjajagan pada bulan Mei 2017, terdapat 634 orang tahanan yang belum mendapatkan vonis, namun 40 diantaranya merupakan tahanan karantina atau mapenaling (masa pengenalan ling-kungan) yang ditempatkan di satu kamar secara bersamaan dengan kasus pidana yang berbedabeda seperti kasus narkoba, korupsi, maupun tindak kriminal umum (pencurian, pembunuhan, penganiayaan, pengeroyokan, dll).

Masa pengenalan lingkungan ini seharusnya dilakukan selama dua bulan, terhitung ketika tahanan tersebut dimasukan atau dititipkan sementara ke dalam Rutan oleh pihak kepolisian, kejaksaan, maupun pengadilan negeri. Selama dua bulan tersebut para tahanan mapenaling dicabut haknya untuk dapat dikunjungi oleh keluarganya serta memanfaatkan fasilitas yang tersedia didalam rutan. Sehingga proses interaksi tahanan mapenaling tersebut hanya terjadi dengan sesama tahanan di dalam kamar karantina. Setelah dua bulan menjalani masa karantina/mapenaling, para tahanan dipindahkan kedalam sel-sel dalam blok tertentu sesuai dengan tindak pidana yang dilakukannya, kemudian mereka ber-gabung dengan tahanan lain yang sama-sama sedang menunggu vonis. Namun, karena terjadinya over capacity jumlah masuknya tahanan baru, yakni setiap harinya terdata lebih dari lima orang, maka tidak heran para tahanan baru hanya men-jalani masa karantina/mapenaling maksimal selama dua minggu dan memindahkan tahanan baru tersebut ke dalam sel tertentu sesuai dengan tindak pidana yang dilakukan-nya untuk bergabung dengan tahanan lain. Akan tetapi, walaupun tahanan tersebut sudah dipindahkan ke dalam sel lain status tahanan tersebut masih dalam pengawasan keamanan atau dengan kata lain tahanan tersebut masih berstatus tahanan karantina, namun haknya untuk dikunjungi keluarga serta memanfaatkan fasilitas Rutan sudah di-perbolehkan.

Hal tersebut tentu saja meng-akibatkan tahanan baru tersebut akan lebih sulit untuk berinteraksi dengan tahanan lain maupun dengan warga binaan yang telah dahulu tinggal didalam sel tersebut. Akibat dari terjadinya over capacity tersebut tentu saja dapat memengaruhi interaksi sosial setiap tahanan, baik itu dari aspek kerjasama, akomodasi atau penyesuaian diri, bahkan terhadap persaingan dan kontravensi antar tahanan. Untuk mengantisipasi masalah yang berkaitan dengan interaksi sosial antar tahanan tersebut tentu saja membutuhkan cara penyelesaian.

Dalam penelitian ini, cara penyelesaian masalah yang dilakukan adalah dengan membentuk suatu kelompok sosialiasi yang bertujuan untuk meningkatkan interaksi sosial para tahanan yang sedang menjalani masa pengenalan lingkungan, yakni dengan cara membantu tahanan dalam membangun sikap dan perilaku mereka agar dapat lebih diterima secara sosial baik di lingkungan Rutan maupun di lingkungan masyarakat ketika mereka bebas. Dengan dilakukannya hal tersebut diharapkan dapat mengubah kognisi, afeksi, dan konasi tahanan tersebut. Adapun kelompok sosialisasi tersebut dilakukan dengan beberapa teknik yaitu metode konseling secara berkelompok, teknik diskusi kelompok, serta teknik dinamika kelompok.

Metode Penelitian Metode penelitian yang digunakan dalam penelitian ini adalah metode penelitian kualitatif dengan pendekatan deskriptif yaitu data berupa kata-kata tertulis/lisan ataupun perilaku yang dapat 
diamati secara holistik (utuh) dari permasalahan penelitian tentang Interaksi Sosial Tahanan Masa Pengenalan Lingkungan di Rumah Tahanan Negara Klas I Kebon Waru Kota Bandung. Tujuan peneliti menggunakan metode ini adalah untuk mendeskripsikan atau menggambar-kan secara detail, tepat dan cermat tentang bagaimana interaksi sosial yang dilakukan oleh tahanan yang sedang men-jalani masa pengenalan lingkungan atau karantina, baik itu interaksi yang dilakukan pada sesama tahanan, maupun antara tahanan dengan petugas pemasyarakatan. Sehingga dengan menggunakan metode ini maka peneliti dapat mendeskripsikan dan memberikan gambaran secara lebih lengkap dan mendalam. Hal tersebut mengacu pada Bogda dan Taylor yang dikutip oleh Moleong (2002:3) yakni Metode kualitatif sebagai prosedur penelitian yang menghasilkan data deskriptif berupa kata-kata tertulis/lisan atau perilaku yang diamati, pendekatan ini diarahkan pada latar dan individu tersebut secara holistic (utuh). Penggunaan metode penelitian kuali-tatif memungkinkan peneliti untuk memberi gambaran secara tepat dan cermat berbagai aspek mengenai komunitas masyarakat dan kegiatan yang diamati. Sugiyono (2012:9) menjelaskan bahwa metode penelitian kualitatif adalah metode penelitian yang digunakan untuk meneliti pada kondisi yang alamiah (sebagai lawannya adalah eksperimen) dimana peneliti adalah sebagai instrumen kunci, teknik pengumpulan data dilakukan secara triangulasi (gabungan), analisis data bersifat induktif, dan hasil penelitian kualitatif lebih menekankan makna dari pada generalisasi. Sumber data penelitian yang digunakan yaitu sumber data primer dan sekunder. Menurut Lofland dan Lofland dalam Moleong (2002:112) bahwa sumber data utama dalam penelitian kualitatif ialah katakata dan tindakan selebihnya adalah data tambahan seperti dokumen dan lain-lain.
Sumber data dari penelitian ini adalah berupa kata-kata, informasi dan tindakan dari informan sebagai sumber data primer. Hal ini sesuai apa yang dikatakan Moleong (2002:90) yang menyebutkan informan adalah orangorang yang berada pada latar penelitian yang dimanfaatkan untuk memberikan informasi tentang situasi dan kondisi latar penelitian. Sumber data sekunder dari penelitian ini berupa data tidak langsung yaitu berbentuk tulisan, arsip data, buku-buku, laporan, dokumentasi kegiatan, foto-foto dan lain-lain. Sumber data dalam penelitian ini adalah informan. Informan dalam penelitian ini terdiri dari informan utama sebagai sumber data primer dan informan pendukung sebagai sumber data sekunder. Pemilihan informan menggunakan teknik purposive (sampel bertujuan), Informan yang dipilih dalam penelitian ini adalah orang-orang yang dapat memberikan informasi yang jelas, akurat dan dapat dipertanggung-jawabkan mengenai aspek-aspek yang di-teliti. Pertimbangan yang dipergunakan dalam pemilihan informan ini diantaranya: 1) Tahanan yang sedang menjalani masa pengenalan lingkungan atu karantina selama kurun waktu yang telah ditentukan Rutan. 2) Tahanan yang berusia 1925 tahun. 3) Tahanan dengan jenis tindak pidana apapun. 4) Bersedia menjadi informan. 5) Mempunyai cukup waktu untuk dimintai informasi. 6) Bukan merupakan tahanan pengamanan. Hal demikian dapat memudahkan peneliti dalam melakukan wawancara maupun mengamati situasi sosial yang diteliti sehingga informasi yang didapatkan peneliti akan sesuai dengan keadaan sebenarnya. Berkaitan dengan pemilihan informan dengan menggunakan teknik purposive sampling (sampel bertujuan) dalam pe-nelitian ini penulis memilih informan utama dari beberapa tahanan mapenaling. Menurut pertimbangan penulis, tahanan yang baru pertama kali masuk pada 
lembaga pemasyarakatan akan mengalami penyesuaian diri yang lebih sulit dibandingkan dengan tahanan residivis, sehingga hal tersebut akan berpengaruh pada bagaimana tahanan tersebut berinteraksi dengan tahanan lain. Kemudian selain itu, pertimbangan penulis dalam memilih informan dengan rentang usia 19-25 tahun karena usia tersebut merupakan usia yang rentan yakni usia peralihan dari masa anak ke masa dewasa, sehingga rentang usia tersebut masih membutuhkan perhatian yang lebih karena masih memiliki emosi yang tidak stabil. Dalam penelitian ini pengumpulan data dilakukan dengan meng-gunakan teknik, antara lain: 1) Wawancara Mendalam (Indepth interview), Wawancara mendalam yaitu teknik pengumpulan data dengan cara wawancara yang mendalam antara peneliti dengan informan. Wawancara ini dimaksudkan untuk mendapatkan informasi yang lebih mendalam. Wawancara yang men-dalam (indepth interview) menurut Bogdan dan Taylor (1984:77) "Pertemuan wawan-cara muka secara langsung antara peneliti dan informan yang diarahkan pada pe-mahaman terhadap perspektif informan tentang kehidupannya, pengalamannya atau situasi yang diekspresikan melalui kata-katanya sendiri." Dalam melaksanakan wawancara mendalam ini peneliti melakukan pertemuan secara intensif dengan informan sehingga peneliti dapat memahami makna dari uraian mereka. Wawancara mendalam dilakukan dengan informan utama yaitu tahanan mapenaling yang bertujuan untuk menggali informasi tentang bagaimana interaksi sosial yang terjalin antara sesama tahanan yang sedang menjalani masa pengenalan lingkungan. Peneliti melakukan wawancara dengan me-recheck kembali informasi yang diperoleh dari informan utama sehingga informasi yang diperoleh benar-benar akurat. 2) Observasi, Observasi adalah teknik pengumpulan data dengan pengamatan dan pencatatan dari obyek yang diteliti.

Teknik ini didasarkan atas pengalaman secara langsung dan memungkinkan peneliti me-lihat dan mengamati dengan melibatkan informan itu sendiri kemudian mencatat perilaku dan kejadian sebagaimana terjadi pada keadaan sebenarnya. Peneliti melakukan observasi ini dengan mengamati interaksi social dalam kegiatan-kegiatan yang dilakukan oleh tahanan mapenaling, adapun salah satu kegiatan yang wajib diikuti tahanan selama menjalani masa pengenalan lingkungan adalah meng-ikuti kegiatan penyuluhan tata tertib aturan Rutan. Setiap memperoleh informasi, peneliti melakukan konfirmasi kembali dengan petugas pemasyarakatan agar informasi yang peneliti peroleh dari pengamatan yang dilakukan di lapangan sesuai dengan keadaan yang sebenarnya. 3) Studi Dokumentasi, teknik studi dokumentasi merupakan pengumpulan data dengan cara mencatat data yang telah ada di tempat penelitian. Teknik studi dokumentasi ini peneliti lakukan dengan cara pengumpul-an data, mempelajari dan mencatat data-data yang diperoleh seperti dokumen-dokumen, foto atau gambar yang terdapat di lokasi penelitian. Tujuan dari teknik ini adalah untuk memperkaya informasi yang ber-hubungan dengan permasalahan penelitian.

Pemeriksaan keabsahan data ini peneliti menggunakan teknik sebagai berikut: 1) Perpanjangan Pengamatan, Pe-nulis kembali ke lapangan kemudian me-lakukan kembali wawancara dengan sumber data yang pernah ditemui, sehingga data yang didapatkan semakin luas, pasti, dan mendalam. 2) Meningkatkan Ketekunan, Teknik ketekunan pengamatan ini dilakukan peneliti dengan mengadakan pengamatan dengan teliti dan rinci secara berkesinambungan terhadap faktor-faktor yang menonjol. Ketekunan pengamatan dimaksudkan untuk menemukan 
ciri dan unsur dalam situasi yang sangat relevan dengan persoalan atau isu yang sedang dicari kemudian memusatkan diri pada hal tersebut secara rinci dan lengkap. Ketekunan pengamatan ini dilakukan dengan cara mengamati secara tekun dan cermat me-ngenai berbagai aktivitas tahanan mapenaling yang berkaitan dengan interaksi sosial. Pengamat-an tersebut dilakukan berulang-ulang pada waktu yang berbeda. Setiap data atau informasi yang diperoleh di recheck kembali agar menghasilkan informasi yang lebih akurat. 3) Triangulasi, triangulasi adalah teknik yang digunakan untuk keperluan pengecek-an data. Teknik triangulasi terbagi kedalam tiga macam yaitu: a) Triangulasi Sumber, membandingkan dan mengecek kembali derajat kepercayaan suatu informasi yang diperoleh melalui orang yang berbeda. Hal ini dapat dicapai dengan cara membanding-kan data hasil pengamatan dengan data hasil wawancara. b) Triangulasi Teknik, membandingkan data yang telah diperoleh dengan isi suatu dokumen yang berkaitan baik diperoleh melalui studi dokumentasi maupun observasi. c) Triangulasi Waktu, di-lakukan dengan cara mengecek kembali data dengan menanyakan kembali pertanyaan yang sama di lain waktu dan situasi yang berbeda. Teknik analisis data yang akan digunakan dalam penelitian ini dilakukan dengan tahapan sebagai berikut: 1) Kategorisasi, merupakan seperangkat tumpukan yang disusun atas dasar pemikiran, pendapat dan kriteria tertentu. Dari hasil pemrosesan satuan, peneliti berupaya mengelompokkan satuan-satuan analisis ke dalam kelompok-kelompok yang memiliki karakter yang sama atau memiliki keterkaitan, dimana data dan informasi dari para tahanan mapenaling sebagai sumber utama dikelompokkan tersendiri, diperkuat dengan pengelompokan data dan informasi informan pendukung, masing-masing pengelompokan tersebut disesuaikan dengan permasalahan penelitian dan sub-sub permasalahannya. Pengakhiran kategori ini, dilakukan oleh peneliti karena telah mencapai kejenuhan kategori yakni peneliti tidak memerlukan data lainnya karena kategori yang disusun sudah me-nunjukkan keteraturan data dan informasi dari para informan sehingga pada pengumpulan data berikutnya tidak menambah informasi baru. 2) Reduksi Data, data yang diperoleh di lapangan jumlahnya cukup banyak, untuk itu perlu dicatat secara teliti dan rinci. Semakin lama peneliti ke lapangan, maka jumlah data akan semakin banyak, kompleks dan rumit, selanjutnya segera dilakukan analisis data melalui reduksi data. Mereduksi data berarti merangkum, memilih hal-hal yang pokok, memfokuskan pada halhal yang penting, dicari tema dan polanya. Dengan demikian data yang telah direduksi akan memberikan gambaran yang lebih jelas dan mem-permudah peneliti untuk melakukan pe-ngumpulan data selanjutnya, dan mencarinya bila diperlukan. Reduksi data dilakukan dengan peralatan elektronik seperti komputer dan memberikan aspek pada kodekode tertentu. 3) Penyajian Data, Setelah data direduksi maka langkah selanjutnya adalah menyajikan data. Penyajian data ini dilakukan dalam bentuk uraian singkat, bagan, hubungan antar kategori, flowchart dan sejenisnya. Penyajian data dalam penelitian kualitatif yang paling sering digunakan untuk menyajikan data adalah dengan teks yang bersifat naratif. Selanjutnya, dalam melakukan penyajian data, selain dengan teks naratif, dapat juga berupa matrik, grafik, network (jejaring kerja) dan chart. 4) Penarikan Kesimpulan, Langkah selanjutnya dalam analisis data penelitian kualitatif adalah penarikan kesimpulan dan verifikasi. Kesimpulan awal yang dikemukakan masih bersifat sementara dan akan berubah jika tidak ditemukan bukti-bukti yang kuat yang akan mendukung pada tahap pengumpulan data berikutnya. Apabila 
kesimpulan yang dikemukakan pada tahap awal didukung oleh bukti-bukti yang valid dan konsisten saat peneliti kembali ke lapangan me-ngumpulkan data maka kesimpulan yang dikemukakan merupakan kesimpulan yang kredibel. Kesimpulan pada penelitian kualitatif mungkin dapat menjawab rumusan masalah yang dirumuskan sejak awal tetapi mungkin juga tidak karena telah dikemukakan bahwa masalah dan rumusan masalah dalam penelitian kualitatif masih bersifat sementara dan akan berkembang setelah peneliti berada di lapangan.

\section{Pembahasan}

Masalah dapat diartikan sebagai perbedaan antara harapan dan kenyataan atau ke senjangan antara situasi yang ada dengan situasi yang sebenarnya. Masalah pada hakikatnya merupakan kebutuhan. Berdasarkan hasil penelitian tentang Interaksi Sosial Tahanan Masa Pengenalan di Rumah Tahanan Negara Klas I Kebon Waru Kota Bandung, terdapat beberapa hal yang menyebabkan interaksi sosial tahanan menjadi tidak dapat berjalan dengan semestinya. Seperti yang disebutkan oleh Kimball Young dan Raymond W. Mack dalam Soerjono Soekanto (2012:54) "Interaksi sosial adalah kunci dari semua kehidupan sosial, oleh karena itu tanpa interaksi sosial tidak akan mungkin ada kehidupan bersama". Setiap manusia bebas melakukan interaksi sosial dimanapun dan dengan siapapun, namun hal tersebut ber-beda untuk para tahanan di dalam sel. Berdasarkan hasil penelitian, dalam kondisi yang serba terbatas interaksi sosial yang dilakukan setiap tahanan terkesan tidak alami. Maksud tidak alami disini adalah bahwa setiap tahanan tidak bebas melakukan interaksi sesuai dengan apa yang dikehendakinya, hal tersebut dikarenakan setiap tahanan terikat dengan aturan-aturan yang ada di dalam Rutan. Selain itu, di dalam sel masih lekat dengan budaya senioritas dimana tahanan yang ber-pengalamanlah yang paling mendominasi, sehingga hal tersebut tentu saja mem-pengaruhi proses interaksi sosial yang ter-jadi antar tahanan di dalam sel karantina. Interaksi sosial yang diteliti dalam hal ini adalah yang menyangkut beberapa aspek yang dijelaskan oleh Gillin dan Gillin dalam Soerjono Soekanto (2011:65) yaitu kerja-sama, akomodasi atau penyesuaian diri, persaingan, dan kontravensi.

\section{Karakteristik Informan Informan} merupakan seorang tahanan yang diduga sebagai tersangka dan dimasukan kedalam Rutan sehingga tahanan tersebut harus menjalani masa pengenalan ling-kungan selama maksimal satu bulan sampai proses sidang dilaksanakan dan men-dapatkan vonis. Jumlah informan sebanyak tiga orang yaitu ketiganya merupakan tahanan yang baru dimasukan kedalam rutan tertanggal $12 \mathrm{Mei}$ 2017 dengan tindak pidana dan usia yang berbeda.

1) Informan $\mathrm{AJ}$ : Informan $\mathrm{AJ}$ berusia 24 Tahun, lahir dan berdomisili di Bandung. Pendidikan terakhir AJ adalah SMA, namun saat ini AJ merupakan mahasiswa non-aktif di salah satu Perguruan Tinggi Negeri di Kota Bandung angkatan 2010, AJ memilih untuk mengambil cuti kuliah dengan alasan bahwa dirinya lebih senang berbisnis dan menghasilkan nilai materil dari pada menuntut ilmu. AJ berasal dari keluarga yang mampu, namun AJ mengaku bahwa dirinya tidak pernah menggunakan uang pemberian dari orangtuanya untuk membeli NAPZA. Orang tua AJ sudah bercerai pada tahun 2009 dan pada saat ini AJ memilih untuk tinggal dengan ibunya karena menurutnya ibunya dapat menjamin AJ secara material daripada ayahnya. Pergaulannya menjadi bebas pasca orangtuanya bercerai sehingga akhirnya AJ terjerumus pada dunia narkotika. AJ berstatus 
tahanan baru ter-tanggal 12 Mei 2017 dengan tindak pidana pasal 112 KUHP tentang Kepemilikan Narkotika dan penjualan Narkotika secara bebas. Selain memiliki dan menjual, AJ juga merupakan pengguna aktif NAPZA golongan II seperti ganja dan extacy. Dilihat dari segi fisik, AJ memiliki tinggi badan yang tidak terlalu tinggi untuk ukuran laki-laki yakni sekitar $165 \mathrm{~cm}$, namun bobot tubuhnya cukup besar sekitar $75 \mathrm{~kg}$. Bentuk wajah AJ cenderung bulat dengan model rambut hampir botak. AJ memiliki warna kulit yang putih dan cukup bersih. 2) Informan AG: Informan AG berusia 23 Tahun, lahir dan berdomisili di Bandung. Pendidikan terakhir AG adalah SMP. AG tidak melanjutkan pendidikannya dikarena-kan kondisi keluarga yang tidak mampu lagi membiayai sekolahnya. Pekerjaan terakhir AG sebelum dinyatakan sebagai tahanan adalah seorang pedagang sayur disalah satu Pasar Besar di Kota Bandung. Pada awalnya AG hanya seorang tukang angkut saja namun berkat keuletannya dari hasil angkut barang tersebut AG bisa mengumpulkan uang dan bekerjasama dengan temannya untuk memutuskan berdagang sayur setiap tengah malam menjelang dini hari. AG sudah berkeluarga dan memiliki satu orang anak yang masih kecil. Istrinya hanya seorang ibu rumah tangga, sehingga istrinya hanya mengandalkan pemberian dari orangtuanya dan hasil penjualan sayur untuk menghidupi dirinya dan anaknya. Selama menjalani hukuman, AG tidak pernah mendapatkan kunjungan dari keluarganya termasuk istri dan anaknya, hal tersebut membuat AG menjadi cemas dan sedih karena tidak mendapatkan dukungan emosional dari keluarganya dan AG beranggapan bahwa keluarganya telah mengasingkan dirinya. AG berstatus tahanan baru tertanggal 12 Mei 2017 dengan tindak pidana pasal 170 dan 351 KUHP tentang pidana umum yaitu penganiayaan dan pengeroyokan. Dilihat dari segi fisik, AG memiliki bentuk tubuh yang tinggi besar sekitar $90 \mathrm{~kg}$ dan tinggi badan $175 \mathrm{~cm}$, berambut botak dengan bentuk wajah yang bulat serta berkulit putih bersih. 3) Informan AS: Informan AS berusia 25 Tahun, lahir di Sukabumi dan berdomisili di Bandung. Pendidikan terakhir AS adalah SMP, namun AS sempat menginjak bangku SMA sampai kelas dua dan tidak dilanjutkan akibat tidak adanya biaya. AS berasal dari keluarga tidak mampu, sehingga walaupun AS belum menyelesaikan bangku sekolah-nya, AS harus merantau dan mencari pekerjaan demi menghidupi dirinya dan keluarganya. Sesampainya di Kota Bandung, AS memiliki pekerjaan sekaligus menikah dengan istrinya dan saat ini dikaruniai seorang anak yang masih kecil, istrinya bekerja sepagai Sales Promotion Girl (SPG) dan AS sendiri merupakan seorang pegawai swasta yang bekerja sebagai server.

Semenjak AS dinyatakan sebagai tahanan, istrinya yang menjadi tulang punggung keluarga untuk menghidupi anaknya tersebut. AS berstatus tahanan baru ter-tanggal $12 \mathrm{Mei}$ 2017 dengan tindak pidana pasal 170 KUHP tentang pidana umum yaitu pengeroyokan. Dilihat dari segi fisik, AS memiliki tubuh yang kurus sekitar $55 \mathrm{~kg}$ dan tinggi badan $180 \mathrm{~cm}$. Bentuk wajahnya bulat, berambut botak dan memiliki kulit sawo matang.

\section{Interaksi Sosial melalui Kerjasama}

Kerjasama adalah suatu usaha bersama antara orang perorangan atau antar kelompok untuk mencapai tujuan bersama. Menurut Gillin dan Gillin dalam Soerjono Soekanto (2011) kerjasama timbul apabila seseorang menyadari bahwa mereka mempunyai kepentingankepentingan yang sama dan pada saat yang bersamaan mempunyai cukup pengetahuan dan kesadaran terhadap diri sendiri untuk memenuhi kepentingan-kepentingan ter-sebut. 
Kerjasama sendiri terbentuk karena adanya kebersamaan rencana dan tujuan antar individu, adanya kemamuan untuk menciptakan rencana dan melaksanakannya, adanya pengetahuan yang cukup dan pengendalian diri yang memadai, serta terciptanya suasana yang menyenangkan diantara pelaku kerjasama. Berdasarkan hasil penelitian, kerjasama yang ditunjukan oleh ketiga informan yang merupakan tahanan masa pengenalan lingkungan (mapenaling) di Rutan Klas I Kebon Waru Kota Bandung ini masih dikatakan kurang nampak. Hal tersebut dikarenakan hak-hak informan untuk dapat memanfaatkan fasilitas yang ada di Rutan masih belum dapat diterimanya secara penuh, seperti kegiatan untuk berolahraga, kegiatan yang berkaitan dengan penyaluran keterampilan dan bakat yang dimilikinya, serta kegiatan beribadah di masjid/gereja. Tahanan mapenaling hanya dapat ber-aktivitas di dalam sel karantina saja, se-hingga interaksi pun hanya terjadi di dalam sel. Kerjasama yang ditunjukkan oleh ketiga informan dalam hal ini pun hanya sebatas partisipasi dalam hal yang menyangkut kebersihan di dalam sel seperti mem-bersihkan sisa-sisa makanan yang ber-ceceran, serta melakukan kegiatan beribadah shalat secara berjama'ah bagi kaum muslim. Namun, ketiga informan mengaku bahwa kegiatan tersebut tidak selalu diikuti oleh seluruh penghuni sel karantina karena masih kurangnya tingkat kesadaran setiap tahanan. Setiap tahanan cenderung bersikap acuh ter-hadap apapun yang dilakukan oleh sesama-nya di dalam sel. Seperti yang dikatakan ketiga informan, mereka tidak memiliki ruang yang bebas untuk dapat melakukan berbagai hal yang mereka inginkan, hal tersebut dikarenakan status mereka merupa-kan tahanan baru yang mengharuskan mereka untuk menghormati tahanan lain yang sudah lebih dahulu tinggal di dalam sel atau tahanan lain yang merupakan residivis. Menurut pengakuan ketiga informan, masih terdapat budaya senioritas di dalam sel karantina, hal tersebut dibuktikan ketika sedang berlangsung obrolan-obrolan di dalam sel, orang-orang yang paling men-dominasi dalam obrolan tersebut adalah tahanan yang sudah lama tinggal di dalam sel serta tahanan residivis. Kemudian secara otomatis setiap tahanan baru menjadikan tahanan yang sudah lama tinggal dalam sel dan tahanan residivis tersebut merupakan panutan mereka selama berada di dalam sel.

\section{Interaksi Sosial melalui Akomodasi}

Akomodasi mempunyai dua arti, yaitu menunjuk pada suatu keadaan dan menunjuk pada suatu proses. Menurut Gillin dan Gillin dalam Soerjono Soekanto (2011) pengertian akomodasi yang menunjuk pada suatu keadaan berarti suatu kenyataan adanya suatu keseimbangan dalam interaksi antar individu dan kelompok sehubungan dengan norma dan nilai sosial yang berlaku di dalam masyarakat. Sedangkan pengertian akomo-dasi yang menunjuk pada suatu proses berarti usahausaha yang dilakukan individu untuk meredakan suatu pertentangan dan kontravensi yang terjadi demi mencapai suatu kestabilan. Akomodasi pasti akan terjadi pada setiap individu ketika menempati suatu tempat yang baru, hal tersebut juga dilakukan oleh setiap tahanan yang baru memasuki lembaga pemasyarakatan. Hal ini merupakan akomodasi yang menunjuk pada suatu keadaan. Berdasarkan hasil penelitian, ketiga informan melakukan penyesuaian diri dengan cara yang sama yaitu berbaur dengan tahanan lain serta memperbanyak obrolan untuk menciptakan keakraban. Secara umum, ketiga informan mengaku tidak sulit untuk menyesuaikan diri dengan tahanan lain dalam sel karantina karena mereka merangkul dan menerima informan dengan baik, serta memberikan informasi-informasi mengenai hukuman 
berupa pasal-pasal dan aturan di dalam sel karantina. Adapun cara berbaur yang dilakukan ketiga informan pun tidak terlepas dari basa-basi dan mengobrol sebagai bentuk penghormat-an kepada tahanan lain yang dianggap lebih tua dan senior. Berdasarkan informasi dari ketiga informan, tidak sedikit pula terdapat tahanan lain yang masih bersikap murung dan memilih untuk tidak berinteraksi dalam sel, hal terserbut dikarenakan mereka masih belum dapat menerima kenyataan mengenai dirinya.

\section{Interaksi Sosial dalam Persaingan}

Menurut Gillin dan Gillin dalam Soerjono Soekanto (2011) persaingan adalah suatu proses sosial yang dilakukan oleh individu atau kelompok untuk saling berlomba atau bersaing dan berbuat sesuatu untuk men-capai suatu kemenangan tanpa adanya ancaman atau kekerasan dari para pelaku. Persaingan akan selalu ada dalam setiap kehidupan, begitu pula di dalam kehidupan tahanan. Setiap tahanan berlomba untuk mendapatkan nilai lebih dimata tahanan lain maupun petugas sesuai degan caranya masing-masing. Berdasarkan hasil penelitian, persaingan yang sering terjadi di dalam sel adalah dalam bentuk mencari perhatian tahanan lain, misalnya dengan sering bersih-bersih sel, sering melakukan ibadah, serta sering bertanya dan mengobrol. Ketiga informan mengaku dengan melakukan kegiatan-kegiatan tersebut merupakan salah satu cara mereka untuk bersaing sehat dengan tahanan lain, hal tersebut juga menjadi pemicu tahanan lain untuk dapat melakukannya. Namun tidak menutup kemungkinan, selalu ada tahanan yang mencari keuntungan disetiap usaha yang dilakukan ketiga informan. Misalnya ketika informan sedang melakukan kegiatan bersih-bersih, ada tahanan lain yang hanya memperhatikan saja tanpa membantu. Biasanya tahanan tersebut adalah tahanan yang dianggap lebih tua dan senior.
Berdasarkan hal tersebut dapat disimpulkan bahwa aspek persaingan yang seharusnya bernilai kompetisi kurang nampak diperlihatkan oleh para tahanan, hal ini dikarenakan kegiatan setiap tahanan setiap harinya hanya berada di dalam sel karantina. Tahanan yang sedang menjalankan masa pengenalan lingkungan tidak diperbolehkan untuk dapat mengikuti kegiatan-kegiatan lain di luar sel.

\section{Interaksi Sosial dalam Kontravensi}

Kontravensi adalah sikap mental ter-sembunyi yang ditandai oleh gejala-gejala adanya ketidakpuasan mengenai seseorang, perasaan tidak suka yang disembunyikan dan kebencian atau keraguan terhadap ke-pribadian seseorang. Kontravensi merupa-kan bentuk proses sosial yang berada didalam persaingan, hal ini ditandai dengan sikap ketidakpasttian, keraguan, dan pe-nolakan sehingga akhirnya menjadi sebuah pertikaian. Berdasarkan hasil penelitian dan informasi dari beberapa pihak Rutan Klas I Kebon Waru, sel karantina merupakan sel yang masih sangat diawasi ketat oleh petugas pengamanan. Hal tersebut dikarenakan sel karantina berisikan tahanantahanan yang baru dan masih labil serta banyak dari mereka yang masih belum menerima kenyataan bahwa dirinya harus menjalankan hukuman dari tindak pidana yang dilakukannya. Hal tersebut tidak menutup kemungkinan dapat menimbulkan kontravensi dari setiap tahananan dalam sel karantina tersebut, namun sejauh pengawas-an petugas belum ada kontravensi hebat yang menyebabkan kekacauan di dalam sel karantina.

Namun dalam hal ini ketiga informan tidak pernah mengalami kesalah-pahaman dan perbedaan pendapat yang menyebabkan timbulnya kontravensi. Hal itu dikarenakan mereka selalu menjaga tingkah laku dan sikapnya agar mereka tetap aman di dalam sel. 


\section{Harapan Informan}

Setiap tahanan yang sedang menjalani masa pengenalan lingkungan (mapenaling) di dalam sel karantina tentu saja memiliki harapanharapan dalam dirinya yang di-tujukan untuk dirinya sendiri, keluarganya, sesama tahanan, atau bahkan harapan untuk lembaga dalam hal ini adalah Rutan. Harapan-harapan tersebut bukan sekedar keinginan belaka, namun juga dapat mem-buat ketiga informan menjadi termotivasi dan bersemangat serta ikhlas dalam men-jalani hukuman atas tindak pidana yang dilakukannya. Berdasarkan hasil penelitian, harapan-harapan tersebut dapat dijabarkan dalam beberapa point berikut ini: 1) Harapan terhadap diri sendiri seperti tidak mengulangi kesalahan yang sama, dimaaf-kan dan diterima kembali oleh keluarga. 2) Harapan pada keluarga seperti keluarga yang senantiasa mendukung dan mendo'a-kan. 3) Harapan terhadap sesama tahanan seperti tidak terjerumus dan melakukan hal yang sama. 4) Harapan terhadap lembaga dan petugas seperti Rutan dapat merangkul dan memenuhi hak setiap tahanan, petugas dapat bersikap ramah.

Simpulan Penelitian yang dilakukan kepada tiga orang informan tahanan mapenaling dan satu orang informan pendukung yaitu tahanan korve atau tahanan pendamping serta satu orang petugas pemasyarakatan dalam hal ini adalah sub-kasie pengamanan yang ber-urusan langsung dengan tahanan mapena-ling. Karakteristik informan dalam peneliti-an pun ini beragam, dari mulai usia, tindak pidana, dan berbagai latar pendidikan. Interaksi sosial dalam hal ini terdiri dari beberapa aspek yang diteliti, diantaranya Aspek Kerjasama, Aspek Akomodasi, Aspek Persaingan, dan Aspek Kontravensi. Berdasarkan hasil penelitian, Kerjasama yang ditunjukkan oleh informan di dalam sel karantina masih dapat dikategorikan kurang, hal tersebut dikarenakan masih lekatnya budaya senioritas antar tahanan baru dan tahanan residivis atau tahanan yang dituakan.

Hal tersebut menjadi sebuah ke-timpangan karena proses kerjasama yang se-harusnya dikerjakan berdasarkan par-tisipasi seluruh tahanan demi mencapai se-buah tujuan tidak berjalan dengan se-mestinya karena masih terdapat budaya seperti itu. Kemudian dari Aspek Akomodasi informan mengaku tidak sulit dalam melakukannya, namun tidak sedikit juga ada tahanan yang murung dikarenakan masih belum dapat me-nerima kenyataan mengenai hukuman yang dijalaninya, sehingga hal tersebut berpengaruh pada interaksinya dengan tahanan lain karena dirinya lebih memilih diam dan tidak mau berbaur dengan sesamanya. Sedangkan dari Aspek Persaingan dan Kontravensi masih belum ditemukan di dalam sel karantina karena sementara tahanan mapenaling dicabut kebebasannya untuk dapat melakukan kegiatan diluar sel dan memanfaatkan fasilitas yang ada di Rutan. Hal tersebut menyebabkan seluruh tahanan tidak dapat berkompetisi dalam hal apapun untuk mendapatkan nilai lebih di mata petugas pemasyarakatan dan tahanan lain. Begitu pula dengan aspek kontravensi tidak ditemukan di dalam sel karantina karena sesama tahanan saling menghargai dan menghormati serta penjagaan masih ketat dilakukan oleh petugas pengamanan Rutan.

Hasil penelitian tersebut menunjukkan bahwa interaksi sosial tahanan mapenaling di Rutan Klas I Kebon Waru Kota Bandung masih dapat dikategorikan kurang khusus-nya pada tahanan yang baru pertama kali menjalani masa hukuman atas tindak pidana yang dilakukannya. 
Hal tersebut dikarena-kan tahanan residivis dan tahanan yang dituakan sangat mendominasi di dalam sel karantina. Berdasarkan analisis permasalahan interaksi sosial tahanan masa pengenalan lingkungan (mapenaling) di Rutan Klas I Kebon Waru Kota Bandung, maka diperlukan upaya pemecahan masalah yang dapat menyentuh interaksi sosial tahanan.

Berdasarkan hal tersebut perlu disusun suatu program yang sistematis sehingga program tersebut dapat dijadikan bekal bagi kehidupan para tahanan selama menjalani masa hukuman dan setelah bebas kembali kepada masyarakat dengan meingkatkan interaksi sosial terutama ter-hadap aspek-aspek Kerjasama, Akomodasi, Persaingan, serta Kontravensi. Sejalan dengan hal tersebut, perlu adanya pemecahan masalah untuk meningkatkan interaksi sosial tahanan mapenaling. Program yang diusulkan oleh peneliti adalah "Peningkatan Interaksi Sosial Tahanan Melalui Kelompok Sosialisasi”, program ini secara umum mempunyai tujuan untuk me-ningkatnya dan mengembangkan ke-mampuan dan kemauan interaksi sosial tahanan sehingga diharapkan dapat tercipta interaksi sosial yang baik, terarah, dan menyeluruh selama berada di Rutan Klas I Kebon Waru Kota Bandung. Kelompok Sosialisasi sendiri dibentuk untuk membantu informan agar dapat berinteraksi sosial dengan sesama tahanan di dalam sel sesuai dengan apa yang dikehendakinya tanpa khawatir hal yang tidak diinginkan terjadi kepada dirinya. Dengan Kelompok Sosialisasi ini, informan dapat diterima secara sosial dan dapat meningkatkan rasa percaya diri mereka terutama dalam hal yang menyangkut dengan interaksi sosial. Kelompok Sosialisasi ini dilakukan dengan beberapa teknik yakni teknik Diskusi Kelompok dan Dinamika Kelompok yang bertujuan untuk merubah kognisi atau kemampuan informan untuk menilai perilaku yang baik maupun perilaku buruk, kemudian untuk merubah afeksi atau perasaan informan yang menyangkut aspek emosional, serta untuk merubah konasi atau perilaku informan yang ditentukan oleh pengetahuan dan perasaan yang dialaminya. Sasaran utama dalam program ini adalah tiga orang informan primer namun juga mengikutsertakan tahanan lain yang samasama sedang menjalani masa pengenalan lingkungan (mapenaling), hal tersebut dilakukan sebagai media untuk membantu proses perubahan interaksi sosial sasaran utama dalam program ini. Adapun pertimbangan dalam menentukan sasaran utama tersebut karena informan merupakan tahanan yang baru pertama kali masuk ke dalam Rutan atas tindak pidana yang dilakukannya, sehingga dengan mengikutsertakan informan dalam program ini diharapkan dapat merubah interaksi mereka menjadi lebih baik. Pada dasarnya dengan diskusi kelompok, setiap anggota kelompok dapat mengungkapkan perasaan-perasasan yang dialami oleh dirinya dan dapat memberikan saran terhadap apa yang dirasakan oleh anggota kelompok lain. Selain itu, dengan pemberian materi diharapkan anggota kelompok dapat mempraktikan hal tersebut pada sikap dan perilakunya di dalam sel sesuai dengan perilaku yang diharapkan.

Pelaksanaan program tersebut memerlukan dukungan dari pihak-pihak yang terkait terutama seluruh petugas pemasyarakatan yang terdapat di Rutan Klas I Kebon Waru Kota Bandung, tahanan yang sedang menjalani masa pengenalan lingkungan (mapenaling), serta tenaga fungsional akademisi seperti pekerja sosial, sehingga dengan adanya dukungan yang diberikan oleh pihak-pihak tersebut program akan terlaksana maksimal dan sesuai dengan tujuan yang hendak dicapai. Program Peningkatan 
Interaksi Sosial Tahanan melalui Kelompok Sosialisasi ini pada dasarnya mengedepankan suatu komunikasi yang baik agar dapat tercipta suatu interaksi yang terarah antar sesama tahanan, yakni dengan menggunakan metode social group work. Metode social group work merupakan metode untuk memecahkan masalah dengan menggunakan media kelompok yang bertujuan untuk membantu tahanan yang mengalami ke-sulitan khususnya yang berkaitan dengan Interaksi Sosial. Penerapan metode ini adalah dengan membentuk dan menentukan komposisi kelompok (beranggotakan 7-10 orang) dan menentukan tujuan kelompok.

\section{Saran}

Suatu program dikatakan berhasil apabila dalam pelaksanaannya terjalin kerjasama dengan beberapa pihak terlibat dalam pelaksanaan program. Pada akhirnya tujuan yang diharapkan pada program ini dapat tercapai dengan maksimal. Agar mem-peroleh hasil yang optimal dalam program, peneliti memberikan rekomendasi pada: 1) Rutan Klas I Kebon Waru Kota Bandung; Hendaknya memberikan dukungan terhadap pelaksanaan program yang dilakukan oleh peneliti baik dukungan yang bersifat finansial, moral, sarana, maupun prasarana dan Memantau perkembangan tahanan selama mengikuti program. 2) Tahanan Masa Pengenalan Lingkungan (Mapenaling); Tahanan dapat mengikuti program dengan sungguh-sungguh sehingga pelaksanaan program menjadi lebih maksimal, Tahanan hendaknya memberikan partisipasi secara aktif selama kegiatan program berlangsung, dan Melaksanakan arahan dan bimbingan pekerja sosial dengan baik. 3) Pekerja Sosial atau Pendamping; Memberikan dukungan dan motivasi pada tahanan yang menjadi sasaran program agar mengikuti berjalannya program kelompok sosialisasi dan Memberikan materi dengan teknik yang menyenangkan sehingga tidak menimbulkan efek bosan bagi para tahanan ketika mengikuti kegiatan.

\section{Daftar Pustaka}

Adi Fahrudin 2012. Pengantar Kesejahteraan Sosial. Bandung: PT. Refika Aditama.

Andi Wijaya Rivai. 2014. Buku Pintar Pemasyarakatan. Jakarta: Lembaga Kajian Pemasyarakatan. M. Ali Arranoval. 2014. Strategi Penerapan Standar Pelayanan Pemasyarakatan. Jakarta: Direktorat Jendral Pemasyarakatan.

Bimo Walgito. 2011. Teori-teori Psikologi Sosial. Yogyakarta: Andi Offset.

Dwi Heru Sukoco. 1995. Profesi Pekerjaan Sosial dan Proses Pertolongannya. Bandung: Koperasi Mahasiswa Sekolah Tinggi Kesejahteraan Sosial (STKS) Bandung.

Herry Koswara, dkk. 2011. Tentang Group Work. Bandung: STKS Press.

Lexy J Moleong. 2011. Metode Penelitian Kualitatif Bandung: Remaja Rosdakarya.

Sarlito W Sarwono. 2013. Pengantar Psikologi Umum. Jakarta: Rajagrafindo Presada. 
Siporin, Max. 1975. Iintroduction to Social Work Practice. New York: MacMillan Pub Co.

Slamet Santoso. 2010. Teori-teori Psikologi Sosial. Bandung: PT Refika Aditama

Soerjono Soekanto. 2012. Sosiologi Suatu Pengantar. Rajawali Pers: Jakarta.

Sugiyono. 2005. Memahami Penelitian Kualitatif. Alfabeta: Bandung.

Sumber lain:

Peraturan Menteri Hukum dan Hak Asasi Manusia Republik Indonesia Nomor 6 Tahun 2013 BAB I Pasal 1 Ayat 2 dan 5 tentang Tata Tertib Lembaga Pemasyarakatan dan Rumah Tahanan Negara.

Peraturan Menteri Hukum dan Hak Asasi Manusia Republik Indonesia Nomor 33 Tahun 2015 tentang Pengamanan Pada Lembaga Pemasyarakatan dan Rumah Tahanan Negara.

Dorang Luhpuri. 2004. Modul Diklat Pekerjaan Sosial Koreksional. Bandung: Depsos RI.

Pengerlife. 2012. Rutan Kebon Waru Bandung. Melalui http://kebonwaru.wordpress.com. Diakses pada 5 Agustus 2016.

Sistem Database Pemasyarakatan. 2016. Data Terakhir Jumlah Penghuni Perkanwil. Melalui http://smslap.ditjenpas.go.id. Diakses pada 10 Agustus 2016. 